\title{
Aquatic macrophytes of six subtropical shallow lakes, Rio Grande, Rio Grande do Sul, Brazil
}

\author{
Sabrina Amaral Pereira, Cláudio Rossano Trindade Trindade, Edélti Faria Albertoni and Cleber \\ Palma-Silva*
}

\begin{abstract}
Universidade Federal do Rio Grande - FURG, Instituto de Ciências Biológicas, Programa de Pós-Graduação em Biologia de Ambientes Aquáticos Continentais. Laboratório de Limnologia. Av. Itália Km 8. CEP 96201-900. Rio Grande, RS, Brazil.

* Corresponding author. E-mail: dmbcps@furg.br
\end{abstract}

\begin{abstract}
The aim of this study was to document the richness of aquatic macrophytes in six shallow lakes at Federal University of Rio Grande - FURG, Rio Grande, Rio Grande do Sul, Brazil. Qualitative surveys were carried out during 2008. Specimens were deposited at the university herbarium (HURG). We recorded 44 species belonging to 35 genera and 21 families. The majority of species were present all year. The family with highest diversity was Cyperaceae (eight species). Other studies have reported approximately 170 species for wetlands in the south of Brazil. This study documented approximately $25 \%$ of these species. The flora of the area should be preserved and monitored.
\end{abstract}

\section{INTRODUCTION}

Shallow lakes are complex ecosystems strongly influenced by physical, chemical and biological processes arising from the intense sediment-water interaction and the potential impact of aquatic vegetation (Scheffer 1998). Aquatic macrophytes play an important role in the structure and function of aquatic ecosystems (Chambers et al. 2008) and therefore participate in nutrient cycling, energy flow, and habitat heterogeneity (Wetzel 1993; Esteves 1998; Albertoni et al., 2005).

Surveys of biological diversity in aquatic ecosystems are essential protective measures because they identify areas of major conservation value (Thomaz and Bini 2003). The high spatial variability of the macrophyte community is an important parameter to be considered in choosing these areas (Rolon et al. 2004). The Rio Grande do Sul coastal plain's low relief and the reduced depth of its water bodies give rise to common, diverse, and dense stands of macrophytes in the littoral zone of the area's lakes (Vieira and Rangel 1988; Albertoni et al. 2005). The current lack of updated information on species composition and on species' spatial and temporal distribution in different environments limits the establishment of guidelines for biodiversity conservation. The objective of this study was to extend current knowledge of aquatic vegetation in this region by surveying the aquatic macrophytes of six shallow lakes during a one-year period.

\section{MATERIALS AND MeThodS}

The city of Rio Grande ( $\left.32^{\circ} 01^{\prime} 40^{\prime \prime} \mathrm{S}, 52^{\circ} 05^{\prime} 40^{\prime \prime} \mathrm{W}\right)$ is located in southern Brazil on the Rio Grande do Sul Coastal Plain. The coastal plain is characterized by low relief and absence of rivers. Streams and ponds constitute the hydrographic network (Vieira and Rangel 1988) (Figure 1).

The climate is humid subtropical (Cfa according to the Köppen classification). The winter and spring are characterized by intense humidity. The summer is dry. NE winds dominate for most of the year. In the autumn, and particularly in winter, S (mainly SE) winds become very important (Krusche et al. 2002).

The study was conducted in six aquatic environments located on the Carreiros campus of the Federal University of Rio Grande in an area of approximately 250 ha. The area has many small natural and artificial bodies of water. During periods of high rainfall, an extensive area remains flooded, and the soil is water saturated.

The lakes studied are permanent, small and shallow, reaching up to $3 \mathrm{~m}$ deep and 3 ha in size. These water bodies have different limnological characteristics (trophic status, dissolved status, dissolved oxygen concentrations, pH) (Albertoni et al. 2005; Marinho et al. 2009; Trindade et al. 2009), and these differences give rise to biological communities peculiar to each water body.

The samples were collected monthly from January to December 2008 using the methods in Pedralli (1990). In each lake, the species were recorded until samples stabilized (no further increase in species found, Filgueiras et al. 1994). The species found were photographed, collected for identification and mounting and deposited in the Herbarium of the Federal University of Rio Grande (HURG). The identification followed the taxonomic literature (Forno 1983; Cordazzo and Seelinger 1988, Cook 1990; Irgang and Gastal Jr. 1996; Cervi and Pott 1999; Gil and Bove 2007; Barros 1960). The species were arranged by family according to APG II - Angiosperm Phylogeny Group (2003). The verification of nomenclature and citation of authors of species found was carried out using the List of Species of Flora of Brazil (Forzza et al. 2010). The species were classified according to morphoecological group as follows: emergent (or amphibious), rooted with floating leaves, submerged rooted, free submerged and free floating (Esteves 1998).

The efficiency of sampling effort was quantified by using the species accumulation curve with 50 randomizations (Colwell 2009), with each monthly collection as the 
sampling unit. To view the pattern of colonization, the species were classified using the following categories according to temporal frequency of occurrence: constant (present in 100\% of collections); frequent (present in 99-50\%), sporadic (present in 49-10\%) and occasional (present in 9-1\%) following Rolon et al. (2004).

\section{RESULTS AND DISCUSSION}

A total of 43 species distributed across 35 genera and 21 families were recorded in the six shallow lakes of the Carreiros campus (Table 1). The species accumulation curve showed a tendency to stabilize and reached saturation in the final samples collected (Figure 4). This result indicates that the sampling effort was sufficient to quantify the macrophyte community on the Carreiros campus.

A few previous surveys of aquatic flora are available for this region. Pedralli et al. (1985) recorded 116 species in the city and its environments. Rocha and Costa (1988) found 21 species of macrophytes in a shallow lake. Approximately $24 \%$ and $43 \%$, respectively, of the taxonomic inventories reported by these previous studies were also recorded in this study. The richness of taxa found in this study represents ca. $25 \%$ of the aquatic macrophytes listed by Rolon et al. (2004) for 146 wetlands in the state of Rio Grande do Sul. Therefore, although the scale of our environments is small, the high diversity of species recorded indicates the conservation importance of the area. The family Cyperaceae was most often represented in our samples. The eight species recorded represented a total of approximately $18.2 \%$ of all species found. Most of the recorded species (33 species) were constant in occurrence and present throughout the study period (Figure 2). The small variation in the number of observed species suggests that most of these species are perennials and can tolerate the environmental changes that occur, such as fluctuations in water levels and size of the systems. For example, during drought periods, species of the family Cyperaceae indicate the existence of temporary swamps (Bove et al. 2003).

Luziola peruviana (Poaceae) was the only species found in all six lakes and over the entire study period (Figure 3). This macrophyte is perennial, amphibious, rooted, with excellent regrowth, reproduction by seed and stolons, and vegetative growth throughout the year (Boldrini et al. 2005). According to Neiff (2000), the dominance of this species may reflect its amphibious adaptations, derived from stolon growth, that allow the plant to follow seasonal changes in the water level.

Among morphoecological groups, emergent and amphibious species were the most representative (28 species), followed by floating (seven species), submerged rooted (four species), submerged free (three species) and rooted with floating leaves (one species). The most representative species of amphibious and emergent macrophytes were also reported by several other authors from diverse aquatic systems (Irgang et al. 1984; Pott and Pott 1997; Matias et al. 2003; Bove et al. 2003; Rolon et
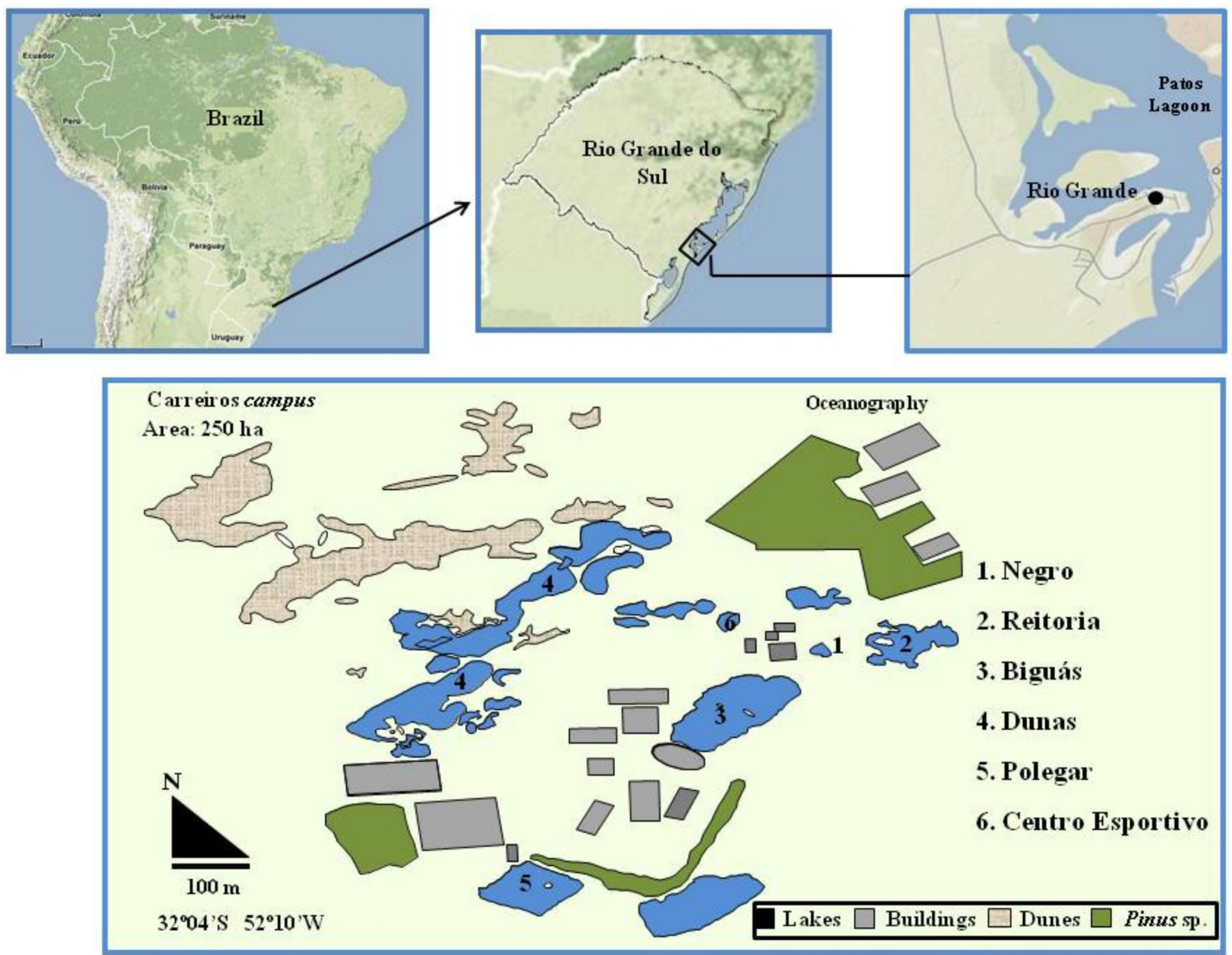

FigURE 1. Map of study area showing the lakes sampled, located on Carrreiros campus, FURG, (Rio Grande, Rio Grande do Sul, Brazil). 
al. 2004). Clearly, these species are well adapted to both aquatic and terrestrial environments (Junk and Piedade 1993).

Floristic surveys of all species are rarely reported. According to RØrslett (1991), survey findings may be affected by the areas and sampling periods included and by human intervention. Thus, some species may not have been recorded because they were in their vegetative state or had biennial life cycles. This observation suggests a need for future studies that focus on the ecological plasticity of these species.
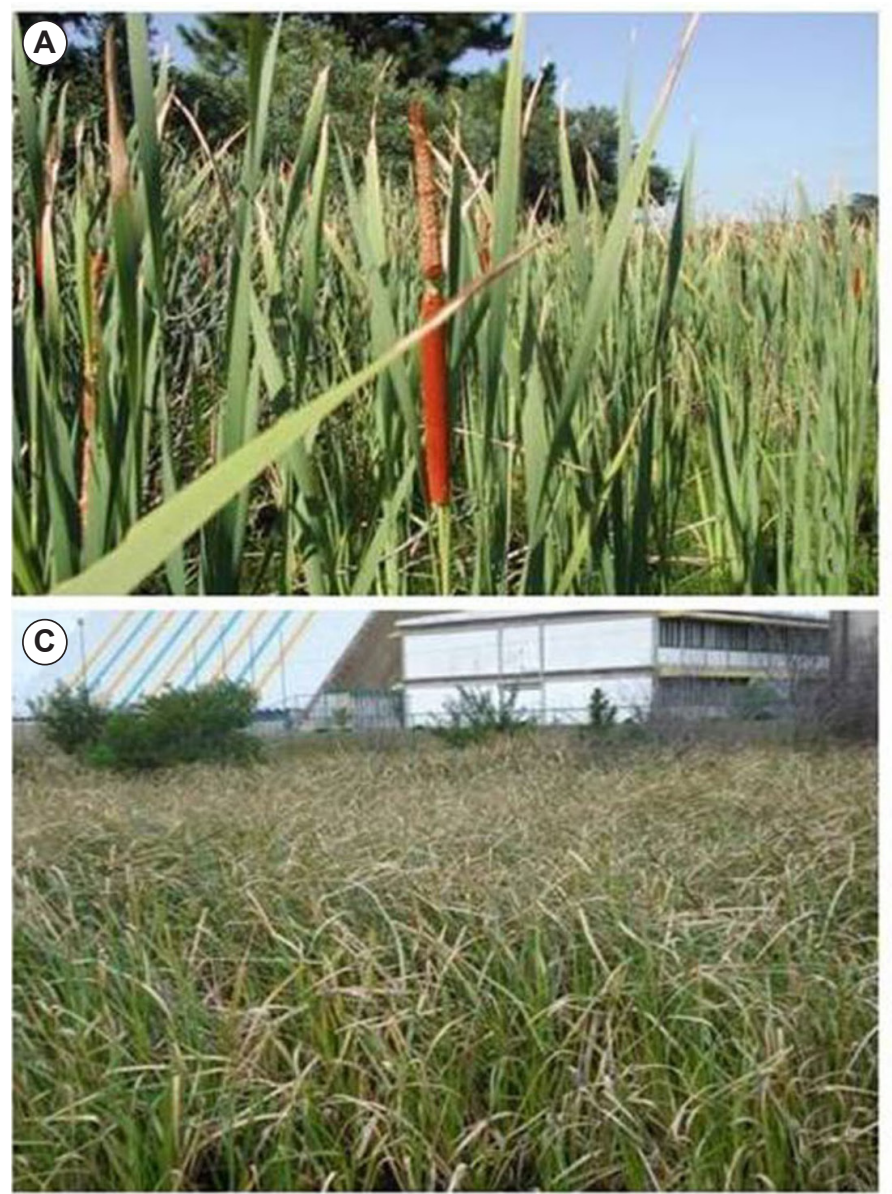

FIGURE 2. Perennial species in different seasons. Typha domingensis: A - summer (January) and B - Winter (June). Scirpus giganteus: C - Winter (June) and D - Spring (September).

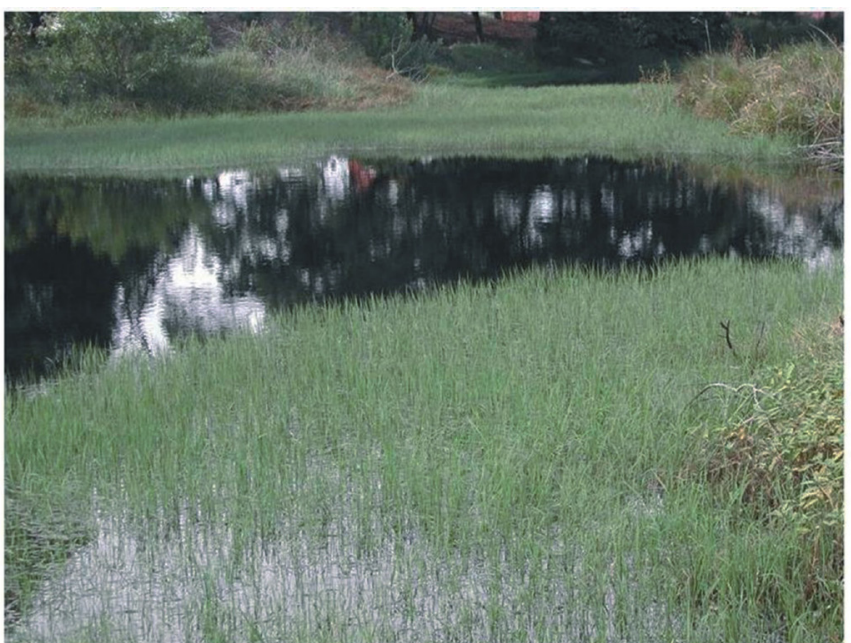

FIGURE 3. Luziola peruviana present in the all lakes during all year.

In this study, we observed high diversity and low variation in the number of species throughout the year, which indicates that the studied area is in a good state of preservation. The fact that macrophyte communities play an important role in the maintenance and function of aquatic ecosystems in the region has strong implications for future research needs. There is a need to deepen and broaden the scope of floristic surveys as well as to focus on the preservation of native species and on maintaining the integrity of these ecosystems.
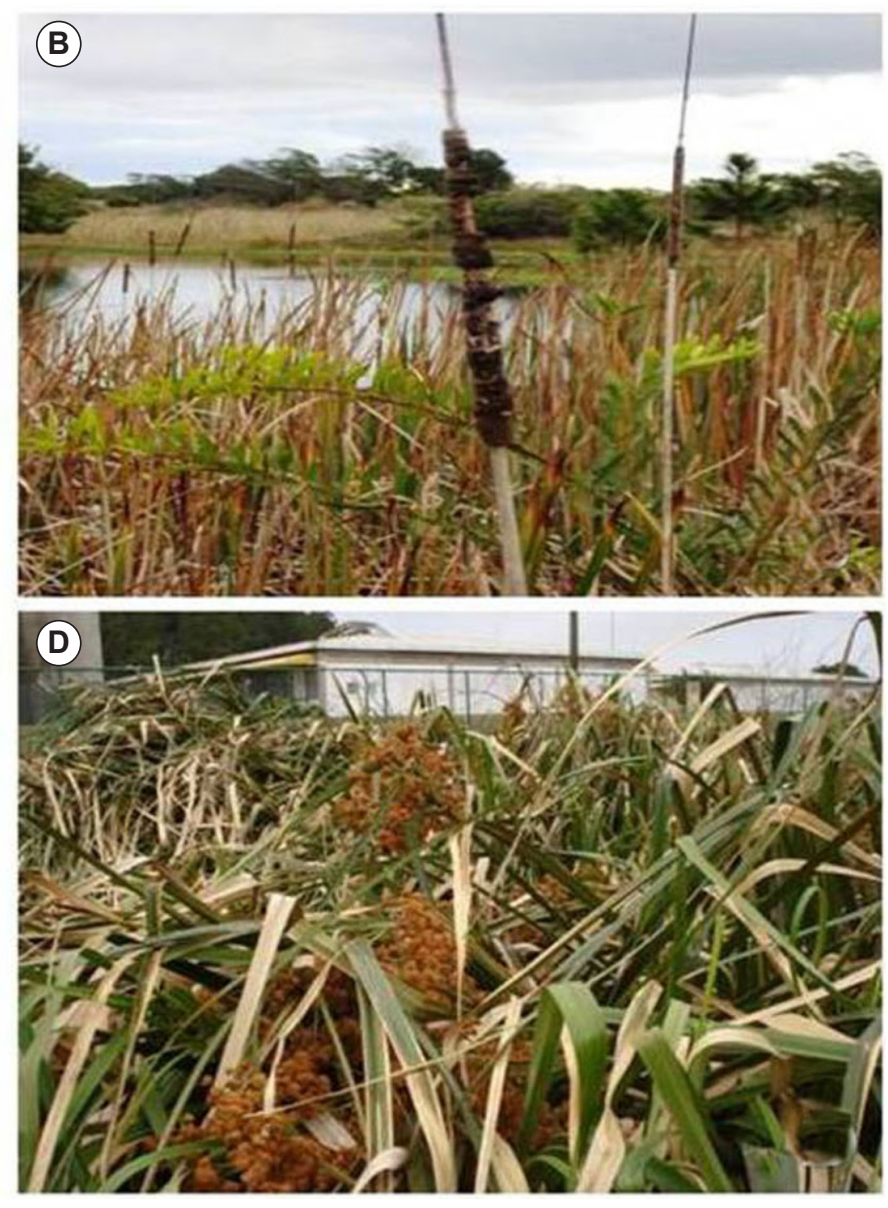

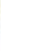


TABLE 1. List of species of macrophytes found in six shallow lakes at Carreiros campus in Rio Grande, Rio Grande do Sul, Brazil. Lakes: D - Dunas, P Polegar. N - Negro, CE - Centro Esportivo e R - Reitoria. $\mathrm{N}^{\circ} \mathrm{HURG}=$ Number of herbarium deposit, FREQ= frequency of species.

\begin{tabular}{|c|c|c|c|c|}
\hline FAMILY / SPECIES & MORPHO-ECOLOGY GROUP & LAKES & $\mathbf{N}^{\circ}$ HURG & FREQ (\%) \\
\hline \multicolumn{5}{|l|}{ ALISMATACEAE } \\
\hline Echinodorus tenellus (Mart.) Buchenau & emergent/amphibious & $\mathrm{D}, \mathrm{P}$ & 4299 & 25 \\
\hline Sagittaria montevidensis Cham. and Schltdl. & emergent/amphibious & $\mathrm{D}$ & - & 100 \\
\hline \multicolumn{5}{|l|}{ AMARANTHACEAE } \\
\hline Alternanthera philoxeroides (Mart.) Griseb. & emergent/amphibious & D, CE, R,N, B & 4292 & 83 \\
\hline \multicolumn{5}{|l|}{ APIACEAE } \\
\hline Centella asiatica (L.) Urb. & emergent/amphibious & D, P, CE, R, B & 4298 & 100 \\
\hline \multicolumn{5}{|l|}{ ARACEAE } \\
\hline Lemna valdiviana Phil. & free floating & $\mathrm{D}, \mathrm{N}, \mathrm{CE}$ & 4462 & 92 \\
\hline Pistia stratiotes L. & free floating & $\mathrm{D}$ & - & 33 \\
\hline Wolffia brasiliensis Wedd. & free floating & $\mathrm{D}, \mathrm{N}$ & 4294 & 33 \\
\hline Wolffiella oblonga (Phil.) Hegelm. & free submerged & $\mathrm{D}, \mathrm{N}$ & 4293 & 100 \\
\hline \multicolumn{5}{|l|}{ ARALIACEAE } \\
\hline Hydrocotyle bonariensis Lam. & emergent/amphibious & $D, P, C E, R, B$ & 1160 & 100 \\
\hline Hydrocotyle ranunculoides L.f. & emergent & $\mathrm{D}, \mathrm{B}$ & 4295 & 100 \\
\hline \multicolumn{5}{|l|}{ ASTERACEAE } \\
\hline Mikania periplocifolia Hook. and Arn. & amphibious & B & 4114 & 100 \\
\hline Enydra anagallis Gardner & emergent/amphibious & D, CE, R, B & - & 100 \\
\hline \multicolumn{5}{|l|}{ САВОМВАСЕАЕ } \\
\hline Cabomba caroliniana A.Gray & submerged rooted & $\mathrm{D}$ & 4458 & 75 \\
\hline \multicolumn{5}{|l|}{ CHARACEAE } \\
\hline Chara sp. & submerged rooted & $\mathrm{D}, \mathrm{P}$ & 4291 & 100 \\
\hline Nitella sp. & submerged rooted & $\mathrm{D}$ & - & 100 \\
\hline \multicolumn{5}{|l|}{ CYPERACEAE } \\
\hline Androtrichum trigynum (Spreng.) H.Pfeiff. & emergent/amphibious & $\mathrm{D}, \mathrm{N}$ & 2104 & 100 \\
\hline Ascolepis brasiliensis (Kunth) Benth. ex C.B.Clarke & emergent/amphibious & B, D, R & - & 100 \\
\hline Cyperus haspan L. & emergent/amphibious & $\mathrm{P}$ & 4454 & 100 \\
\hline Cyperus odoratus L. & emergent/amphibious & CE, R, B & - & 83 \\
\hline Cyperus rigens C.Presl & emergent/amphibious & $\mathrm{D}, \mathrm{N}$ & 4453 & 100 \\
\hline Pycreus polystachyos (Rottb.) P.Beauv. & emergent/amphibious & B & 4455 & 100 \\
\hline Schoenoplectus californicus (C.A.Mey.) Soják & emergent/amphibious & D, P, B & - & 100 \\
\hline Scirpus giganteus Kunth & emergent/amphibious & $\mathrm{D}$ & - & 100 \\
\hline \multicolumn{5}{|l|}{ FABACEAE } \\
\hline Erythrina crista-galli L. & emergent/amphibious & B & & 100 \\
\hline Vigna luteola (Jacq.) Benth. & emergent/amphibious & $\mathrm{D}, \mathrm{B}$ & & 17 \\
\hline \multicolumn{5}{|l|}{ LENTIBULARIACEAE } \\
\hline Utricularia breviscapa C.Wright ex Griseb. & free submerged & $\mathrm{D}, \mathrm{N}, \mathrm{CE}, \mathrm{R}$ & 4297 & 100 \\
\hline Utricularia gibba L. & free submerged & $D, N, C E, R$ & 2401 & 100 \\
\hline \multicolumn{5}{|l|}{ MENYANTHACEAE } \\
\hline Nymphoides indica (L.) Kuntze & rooted with floating leaves & $\mathrm{D}, \mathrm{P}, \mathrm{R}$ & 0789 & 100 \\
\hline \multicolumn{5}{|l|}{ ONAGRACEAE } \\
\hline Ludwigia multinervia (Hook. and Arn.) Ramamoorthy & emergent/amphibious & $\mathrm{D}, \mathrm{CE}, \mathrm{R}$ & 4324 & 100 \\
\hline Ludwigia hexapetala (Hook. and Arn.) Zardini et al. & emergent/amphibious & $D, N, C E, R, B$ & 4302 & 100 \\
\hline Ludwigia peploides (Kunth) P.H.Raven & emergent/amphibious & $D, N, C E, R, B$ & 1097 & 100 \\
\hline \multicolumn{5}{|l|}{ PLANTAGINACEAE } \\
\hline Bacopa monnieri (L.) Pennell & emergent/amphibious & D, P, CE, R, B & - & 100 \\
\hline \multicolumn{5}{|l|}{ POACEAE } \\
\hline Luziola peruviana Juss. ex J.F.Gmel. & emergent/amphibious & D, P, N, CE, R, B & 1214 & 100 \\
\hline \multicolumn{5}{|l|}{ POLYGONACEAE } \\
\hline Polygonum ferrugineum Wedd. & emergent/amphibious & $\mathrm{D}, \mathrm{N}, \mathrm{B}$ & 4461 & 100 \\
\hline Polygonum hydropiperoides Michx. & emergent/amphibious & $D, N, R, B$ & 2551 & 100 \\
\hline \multicolumn{5}{|l|}{ PONTEDERIACEAE } \\
\hline Eichhornia crassipes (Mart.) Solms & free floating & $\mathrm{CE}, \mathrm{R}$ & - & 100 \\
\hline \multicolumn{5}{|l|}{ POTAMOGETONACEAE } \\
\hline Potamogeton pectinatus L. & submerged rooted & $\mathrm{D}, \mathrm{CE}$ & 4296 & 100 \\
\hline
\end{tabular}


TABle 1. Continued.

\begin{tabular}{|c|c|c|c|c|}
\hline SALICACEAE & & & - & \\
\hline Salix humboldtiana Willd. & emergent/amphibious & $\mathrm{B}$ & - & 100 \\
\hline \multicolumn{5}{|l|}{ SALVINACEAE } \\
\hline Azolla filiculoides Lam. & free floating & $D, C E, N, R, B$ & 4460 & 100 \\
\hline Salvinia herzogii de la Sota & free floating & $\mathrm{D}$ & 4303 & 100 \\
\hline Salvinia minima Baker & free floating & $\mathrm{D}$ & - & 100 \\
\hline \multicolumn{5}{|l|}{ TYPHACEAE } \\
\hline Typha domingensis Pers. & emergent/amphibious & $\mathrm{D}$ & 1209 & 100 \\
\hline \multicolumn{5}{|l|}{ XYRIDACEAE } \\
\hline Xyris jupicai Rich. & emergent/amphibious & $D, P, C E, R$ & - & 83 \\
\hline
\end{tabular}

\section{Literature Cited}

Albertoni, E.F., C. Palma-Silva and C.C. Veiga. 2005. Estrutura da comunidade de macroinvertebrados associada às macrófitas aquáticas Nymphoides indica e Azolla filliculoides em dois lagos subtropicais (Rio Grande, RS, Brasil). Acta Biologica Leopondensia 27(3): 137-145.

Barros, M. 1960. Las ciperáceas del Estado de Santa Catalina. Sellowia 12: 181-448.

Boldrini, I.I., H.M. Longhi-Wagner and S.C. Boechat. 2005. Morfologia e Taxonomia de Gramíneas Sul-Rio-Grandenses. Porto Alegre: UFRGS. $96 \mathrm{p}$.

Bove, C.P., A.S.B. Gil, C.B. Moreira and R.F.B. Anjos. 2003. Hidrófitas fanerogâmicas de ecossistemas aquáticos temporários da Planície Costeira do estado do Rio de Janeiro, Brasil. Acta Botanica Brasiliensis 17(1): 119-135.

Chambers, P.A., P. Lacoul, K.J. Murphy and S.M. Thomaz. 2008. Global diversity of aquatic macrophytes in freshwater. Hidrobiologia 594: 9-26.

Cordazzo, C.A. and U. Seeliger. 1988. Guia Ilustrado da Vegetação Costeira No Extremo Sul Do Brasil. Rio Grande: FURG. 275 p.

Colwell, R.K. 2009. Estimates: Statistical Estimation of Species Richness and Shared Species from Samples. Version 8.2. User Guide. Electronic database accessible at http://viceroy.eeb.uconn. edu/estimates. Captured on 16 August 2010.

Esteves, F.A. 1998. Fundamentos de Limnologia. 2a Edição. Rio de Janeiro: Interciência - FINEP. 575 p.

Filgueiras, T.S., P.E. Nogueira, A.L. Brochado and G.F. Guala. 1994. Caminhamento: um método expedito para levantamentos florísticos qualitativos. Cadernos de Geociências 12: 39-43.

Forno, I.W. 1983. Native distribution of the Salvinia auriculata complex and keys to species identification. Aquatic Botany 17(1): 71-83.

Forzza, R.C., P.M. Leitman, A.F. Costa, A.A. Carvalho Jr., A.L. Peixoto, B.M.T Walter, C. Bicudo, D. Zappi, D.P. Costa, E. Lleras, G. Martinelli, H.C. Lima, J. Prado, J.R. Stehmann, J.F.A. Baumgratz, J.R.irani, L. Sylvestre, L.C. Maia, L.G. Lohmann, L.P. Queiroz, M. Silveira, M.N. Coelho, M.C. Mamede, M.N.C. Bastos, M.P. Morim, M.R. Barbosa, M. Menezes, M. Hopkins, R. Secco, T.B. Cavalcanti and V.C. Souza. (Org.). 2010. Lista de Espécies da Flora do Brasil. Jardim Botânico do Rio de Janeiro. Electronic database accessible at: http://floradobrasil.jbrj.gov.br. Captured on 20 de Agosto de 2010.

Gil, A.S.B and C.P. Bove. 2007. Eleocharis R.Br. (Cyperaceae) no Estado do Rio de Janeiro, Brasil. Biota Neotropica 7(1): 163-193.

Irgang, B.E., G. Pedralli and J.L. Waechter. 1984. Macrófitos aquáticos da Estação ecológica do Taim, Rio Grande do Sul. Roessleria 6: 395-404.

Irgang, B.E. and C.V.S. Gastal. 1996. Macrófitas Aquáticas da Planície Costeira do RS. Porto Alegre. 290p.

Junk, W.J. and M.T.F. Piedade. 1993. Herbaceous plants of Amazon floodplain near Manaus: Species diversity and adaptations to the flood pulse. Amazoniana 12(3/4): 467-484.

Krusche, N., J.M.B. Saraiva and M.S. Reboita. 2002. Normais climatológicas provisórias de 1991 a 2000 para Rio Grande, RS. Rio Grande. 104p.

Marinho, C.C., C. Palma-Silva, E.F. Albertoni, C.R.T. Trindade and F.A. Esteves. 2009. Seasonal dynamics of methane in the water colum of two subtropical lakes differing in trophic status. Brazilian Journal of Biology 69(2): 281-287.
Matias, L.Q., E.R. Amado and E.P. Nunes. 2003. Macrófitas aquáticas da lagoa da Jijoca de Jericoacoara, Ceará, Brasil. Acta Botanica Brasílica $17(4): 623-631$.

Neiff, J.J. 2000. Diversity in some tropical wetland systems of South America; p. 1-32 In B. Gopal and W. Junk (ed.). Wetlands Biodiversity. Volume II. Backhuys Publish.: The Netherlands.

Pedralli, G. 1990. Macrófitos aquáticos: técnicas e métodos de estudos. Estudos de Biologia 26: 5-24.

Pedralli, G., B.E. Irgang and C.P. Pereira. 1985. Macrófitas aquáticos do município de Rio Grande, Rio Grande do Sul, Brasil. Agros 20(1/4): 45-52.

Pott, V.J. and A.C. Cervi. 1999. A família Lemnaceae Gray no Pantanal (Mato Grosso e Mato Grosso do Sul), Brasil. Revista Brasileira de Botânica 22(2): 153-174

Pott, V.J. and A. Pott. 1997. Checklist das macrófitas aquáticas do Pantanal, Brasil. Acta Botanica Brasilica 11: 215-227.

Rocha, C.T. and C.S.B. Costa. 1988. Ordenação e distribuição das macrófitas vasculares de um pequeno lago de águas doces e rasas em Rio Grande (RS). Ciência e Cultura 40(2): 164-172.

Rolon, A.S., T. Lacerda, L. Maltchik and B.E. Irgang. 2004. Levantamento de macrófitas aquáticas em áreas úmidas do Rio Grande do Sul, Brasil. Acta Limnologica Leopoldensia 26(1): 17-35.

RØrslet, B. 1991. Principal determinant of aquatic macrophyte richness in northern European lakes. Aquatic Botany 39(1-2): 173-193.

Scheffer, M. 1998. Ecology of Shallow lakes. London: Chapman \& Hall. 357 p.

Thomaz, S.M. 2002. Fatores ecológicos associados à colonização e ao desenvolvimento de macrófitas aquáticas e desafios de manejo. Planta Daninha 20: 21-33.

Thomaz, S.M. and L.M. Bini. 2003. Análise crítica dos estudos sobre macrófitas aquáticas desenvolvidos no Brasil; p. 19-38. In Thomaz, S.M. e L.M. Bini (ed.) Ecologia e manejo de Macrófitas Aquáticas. Maringá: UEM.

Thomaz, S.M., L.M.Bini,T.A.Pagioro, K.J.Murphy, A.M. Santos and D.C. Souza. 2004. Aquatic macrophytes: Diversity, Biomass and Decomposition. Chapter 15; p. 331-352. In S.M. Thomaz, A.A. Agostinho and N.S. Hahn (ed.). The Upper Paraná River and its Floodplain: Physical aspects, Ecology and conservation. Leiden: Backhuys Publishers.

Trindade, C.R.T., L.M. Furlanetto and C. Palma-Silva. 2009. Nycthemeral cycles and seasonal variation of limnological factors of a subtropical shallow lake (Rio Grande, RS, Brazil). Acta Limnologica Brasilensia 21(1): 35-44.

Vieira, E.F. 1983. Rio Grande. Geografia Física, Humana e Econômica. Porto Alegre: Sagra. 158p.

Vieira, E.F. and S.R.S. Rangel. 1988. Planície Costeira do Rio Grande do Sul. Geografia Física, Vegetação e Dinâmica Sócio-Demográfica. Porto Alegre: Sagra. 256p.

Wetzel, R. G. 1993. Limnología. Lisboa: Fundação Calouste Gulbenkian. 919 p.

RECEIVED: March 2011

ACCEPTED: February 2012

Published ONLINE: May 2012

EDITORIAL RESPONSIBILITY: Frederico Augusto Guimarães Guilherme 